\title{
YOUTH UNEMPLOYMENT AND ENTREPRENEURSHIP IN SERBIA
}

The problem of unemployment is one of the key questions of every modern economy and one of the most important indicators of its erfficiency. A higher level of entrepreneurial interest and activities can be an important part of economic growth. However, most citizens, especially young people, are more oriented towards finding work in existing companies than starting their own business. Therefore, the primary goal of the research is better understanding of the interests of senior students at universities in Serbia, in terms of entrepreneurial careers and identifying the key factors that influence them. The study is based on a modification of social cognitive theory model, focusing primarily on the interests and goals of students in terms of entrepreneurship.

Keywords: unemployment, entrepreneurship, career, founding one's own business, interests and goals of young people.

Faculty of Business Studies, Megatrend University; atosovic@megatrend.edu.rs

** Karolinska University Hospital; darko@neam.se 


\section{Introduction}

All countries have been facing the unemployment issue for a long time. A large percentage of unemployment causes concerns because of all socio-economic factors that cause this phenomenon directly. First of all, it disrupts the economic welfare, reduces economic output, decreases human capital, and increases the rate of crime and social instability.

According to the report of the International Labor Organization, ${ }^{1}$ the number of the unemployed in 2014 was 201 million people. The problem of unemployment is present not only in the developing countries, but also in the advanced and developed ones, with young people making the majority of the total number of the unemployed. Global unemployment rate among the young was $13 \%$ in 2014, compared to $12.8 \%$ in 2012 and $11.5 \%$ in 2007 . This means that 73.6 million young people were unemployed worldwide in 2014 , with an increase of 4.1 million since 2007 .

In Serbia, the unemployment rate in 2014 was $22.2 \%$. This figure is expected to decline slightly to $17.7 \%$ in 2019 . However, the trend of high unemployment rate among the young will continue in the forthcoming years, with minor variations. ${ }^{2}$

Based on these indicators, the question is why young people, mostly affected by the problem, are not more oriented toward setting up their own business in order to provide jobs and opportunities for advancement. Starting one's own business means creating business, and not waiting to get work from somebody else, as well as being ready to take risks while realizing one's own ideas into practice.

Therefore, an entrepreneur can be characterized as someone who starts a new business, who recognizes an opportunity and creates the appropriate organization to take advantage of the opportunity. ${ }^{3}$ Furthermore, according to Timmons, entrepreneurship can be defined as the ability to create something practical out of nothing as well as the ability to create a team of associates who will be able to solve a number of strategic and operational problems in business. ${ }^{4}$

For the purposes of this CEVES research on the attitudes on entrepreneurship, the question what type of job they want, or the means of ensuring the existence for which citizens would opt for if they could choose, looks like this: ${ }^{5}$

International Labour Organization (2014): World of Work Report 2014: Developing with jobs / International Labour Office. Geneva: ILO, 2014

Ibid.

Bygrave W. D., Zacharakis A. (2010): Entrepreneurship. Wiley, 2 edition.

Avlijaš, R. (2010): Preduzetništvo. Beograd, Univerzitet Singidunum.

Centar za visoke ekonomske studije - CEVES (2014): Preduzetništvo u Srbija - nužda ili prilika, Beograd, www.ceves.org.rs. 
- $\quad 30 \%$ opted for the option - Start your own business (meaning setting up your own company, doing the business on your own or having your agency)

- $65 \%$ opted for the option - To work for salary in the public sector (public sector comprises state or municipal administration, education, health care and similar services, as well as public enterprises)

- $5 \%$ opted for the option - To work for salary in the private sector (private sector includes large, medium or small domestic or foreign enterprises).

CEVES study ${ }^{6}$ points out that self-employment decreases with age, meaning that the young prefer it more, those aged from 18 to 29 (36\%), and the ones who like it the least, are older than 60 (23\%). In addition, men are more prone to entrepreneurship (33\%) than women (27\%), as well as the ones who have secondary school degree (33\%) than the less educated (26\%) and the highly educated (28\%).

Another study conducted in Serbia by the non-governmental organization Pro Concept ${ }^{7}$ states that young people are not familiar with entrepreneurship and that they are more oriented towards finding a job than setting up their own. Insufficient knowledge and even fear of failure are some of the reasons for the lack of entrepreneurial spirit with the young. Moreover, the education system does not do enough to expand the entrepreneurial spirit. Although entrepreneurship and innovation are self-motivated efforts of creative individuals and / or groups, this does not mean that the role of the state is marginal. ${ }^{8}$

Consequently, the survey was conducted among students in their final year of studies at universities in Serbia in order to get information about the level of interest and goals of students in terms of starting their own business after graduation. In order to have a better insight into all the circumstances regarding the unemployed issue, the analysis of unemployment of the young in Serbia has been conducted.

\section{Analysis of youth unemployment in Serbia}

Unemployment is one of the key macroeconomic problems that the countries of the Western Balkans have been facing during the process of transition. Compared to European Union countries, unemployment in this part of Europe is four to five times higher. However, a surprising and worrying fact is that youth unemployment rate is extremely high in both developed and less developed countries of Europe, as well as worldwide.

Ibid.

ProConcept. (2009): Smisli Biznis, Osnovna Projektna Studija, http://smislibiznis.rs/322/

8 Petrović, D. (2016): Makroekonomski ambijent u funkciji podsticanja inovacija I preduzetništva - primer države Izrael -, Megatrend Review, Vol. 13 (1) 2016, 1-35. 
According to the National Employment Service ${ }^{9}$ and the records for 2015, in Serbia, the young ones are waiting for a job for two years on an average, and currently there are 186,000 registered unemployed persons up to 30 years of age, which is about 25.3 per cent out of the total number of the unemployed. At the conference entitled "Youth unemployment - from desire to careers, how to get a job" Neda Milanovic from the National Employment Service pointed out that Serbia has a very high youth unemployment rate, twice the size compared to the general population of unemployment, specifying that it amounts to $43.1 \%$ while the unemployed of those aged up to 30 accounts for 118,614 people, $63.8 \%$ of whom are fist-time job seekers. ${ }^{10}$

The study worth mentioning here is The young in Serbia at the beginning of the 21st century ${ }^{11}$, dealing with the problem of young people, providing constructive suggestions how to reduce or overcome problems in the future. The study states that from 1991 to 2011 there was a steady decline in the total population by $8.1 \%$, and in the number of young people since 1981 by as much as $25.2 \%$ (Chart 1). An additional problem was reflected in the "low" rate of natural unemployment. ${ }^{12}$ The specific situation in Serbia, which is characterized by low standards, high percentage of unemployment, as well as a lot of other problems and challenges that young people face, led to moving up the upper limit of youth to the age of thirty. ${ }^{13}$

Figure 1. Young people in the Republic of Serbia, without Kosovo and Metohija, research in the number of population 1948 - 2011.

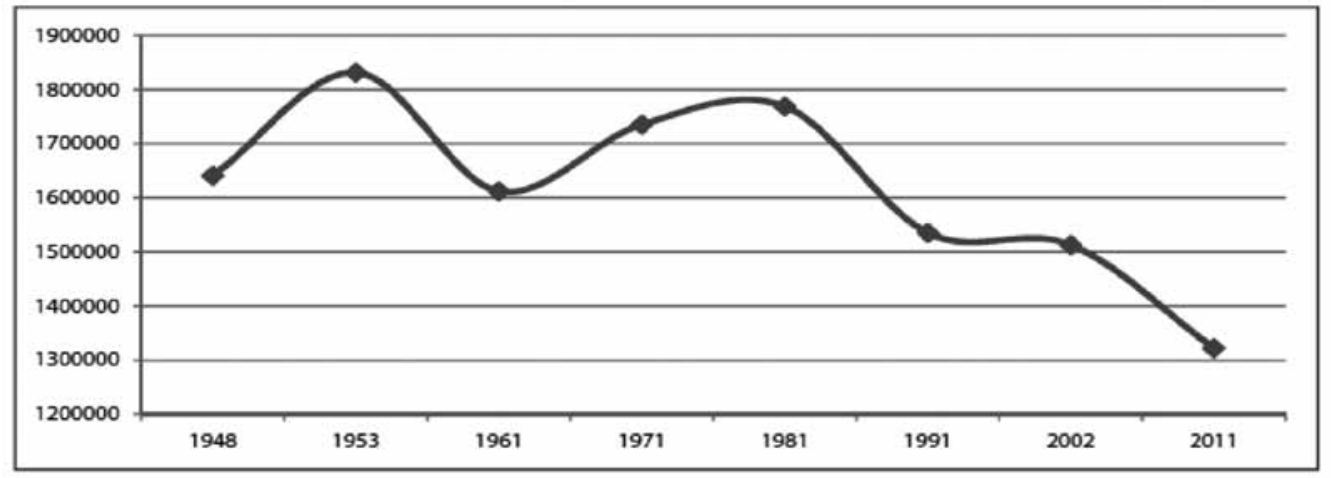

Source: Bubalo-Živković \& Lukić, 2015.

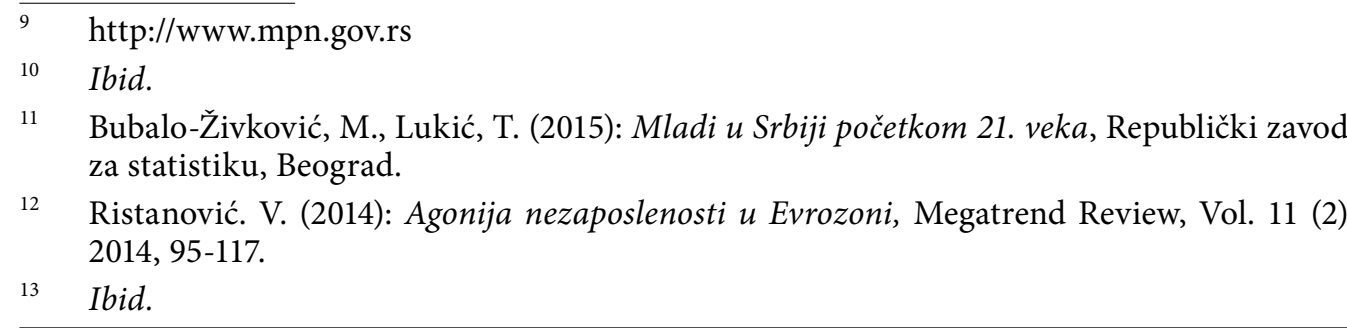


Consequently, an additional concern is the fact that this category of population, which should be most active is in the worst position, as it can be seen in Table number 1.

Table 1. Population by activity status, age group, region and type of settlement, 2014.

\begin{tabular}{|c|c|c|c|c|c|c|c|c|}
\hline & & \multicolumn{2}{|c|}{ Srbija - north } & \multicolumn{3}{|c|}{ Srbija - south } & \multicolumn{2}{|c|}{$\begin{array}{c}\text { Type of } \\
\text { settlement }\end{array}$} \\
\hline & Total & $\begin{array}{c}\text { Belgrade } \\
\text { region }\end{array}$ & $\begin{array}{l}\text { Vojvodina } \\
\text { region }\end{array}$ & $\begin{array}{c}\text { Šumadija } \\
\text { and West } \\
\text { Serbia } \\
\text { region }\end{array}$ & $\begin{array}{c}\text { South } \\
\text { and East } \\
\text { Serbia } \\
\text { region }\end{array}$ & $\begin{array}{l}\text { Kosovo } \\
\text { and } \\
\text { Metohija } \\
\text { region }\end{array}$ & Urban & Other \\
\hline \multicolumn{9}{|c|}{ Population aged 15 and over } \\
\hline Activity rate & 48,9 & 46,8 & 49,1 & 51,4 & 47,8 & $\ldots$ & 47,6 & 50,9 \\
\hline Employment rate & 39,7 & 38,7 & 39,3 & 42,5 & 37,6 & $\ldots$ & 37,6 & 42,8 \\
\hline Unemployment rate & 18,9 & 17,4 & 19,9 & 17,3 & 21,3 & $\ldots$ & 21 & 15,9 \\
\hline Inactivity rate & 51,1 & 53,2 & 50,9 & 48,6 & 52,2 & $\ldots$ & 52,4 & 49,1 \\
\hline \multicolumn{9}{|c|}{ Young-age population (15-24) } \\
\hline Activity rate & 28 & 23,2 & 32,3 & 27,1 & 28,5 & $\ldots$ & 23,5 & 34,4 \\
\hline Employment rate & 14,8 & 11,6 & 18,5 & 15 & 13,3 & $\ldots$ & 11,2 & 20 \\
\hline Unemployment rate & 47,1 & 50,2 & 42,8 & 44,7 & 53,4 & $\ldots$ & 52,3 & 41,8 \\
\hline Inactivity rate & 72 & 76,8 & 67,7 & 72,9 & 71,5 & $\ldots$ & 76,5 & 65,6 \\
\hline \multicolumn{9}{|c|}{ Working-age population (15-64) } \\
\hline Activity rate & 61,8 & 61,6 & 61,9 & 62,8 & 60,5 & $\ldots$ & 61,2 & 62,7 \\
\hline Employment rate & 49,6 & 50,7 & 49,3 & 51,1 & 46,9 & $\ldots$ & 48,2 & 51,8 \\
\hline Unemployment rate & 19,7 & 17,6 & 20,3 & 18,7 & 22,6 & $\ldots$ & 21,2 & 17,4 \\
\hline Inactivity rate & 38,2 & 38,4 & 38,1 & 37,2 & 39,5 & $\ldots$ & 38,8 & 37,3 \\
\hline
\end{tabular}

Source: Statistical Office of the Republic of Serbia, 2015.

According to Statistical Office of the Republic of Serbia, based on the Labour Force Survey for $2014^{14}$, the unemployment rate is the percentage of the unemployed out of the total number of active population of working age, and in 2014, the unemployment rate was the highest among the young population (aged $15-24)$. It was $47.1 \%$, while the rate of unemployment among the population aged 15 years and over amounted to $18,9 \%$, with working age population (1564) being $19.7 \%$. These significant differences point to the necessity of taking appropriate measures to overcome the major issue of unemployment problem of the young people. It can also be noticed that the unemployment rate recorded among young population (15-24) is the highest in Belgrade region (50.2\%) and the lowest in the region of Vojvodina (42.8\%). According to the type of settle-

14 Statistical Office of the Republic of Serbia. (2015): Labour Force Survey, 2014. Statistical Office of the Republic of Serbia, Belgrade. 
ment, the unemployment rate is higher in the city (52.4\%) than in rural areas (49.1\%).

In the Labour Force Survey, ${ }^{15}$ the self-employed are defined as the persons who work independently in their own company, institution, private shops or on farms, as well as the persons performing an independent professional activity or any other business activity for themselves. Based on data from the Labour Force Survey for $2013,{ }^{16}$ the structure of employed persons by employment status was: employed workers $67.5 \%$, self-employed $24.8 \%$ and family workers who provide help $7.7 \%$. As we can see in Graph 2, the lowest percentage of self-employed population is by far in the three categories among the population of 15-19, 20-24 and 25-29 (when analyzing the structure of the population 15-65).

Figure 2. The structure of employed persons according to employment status, 2013.

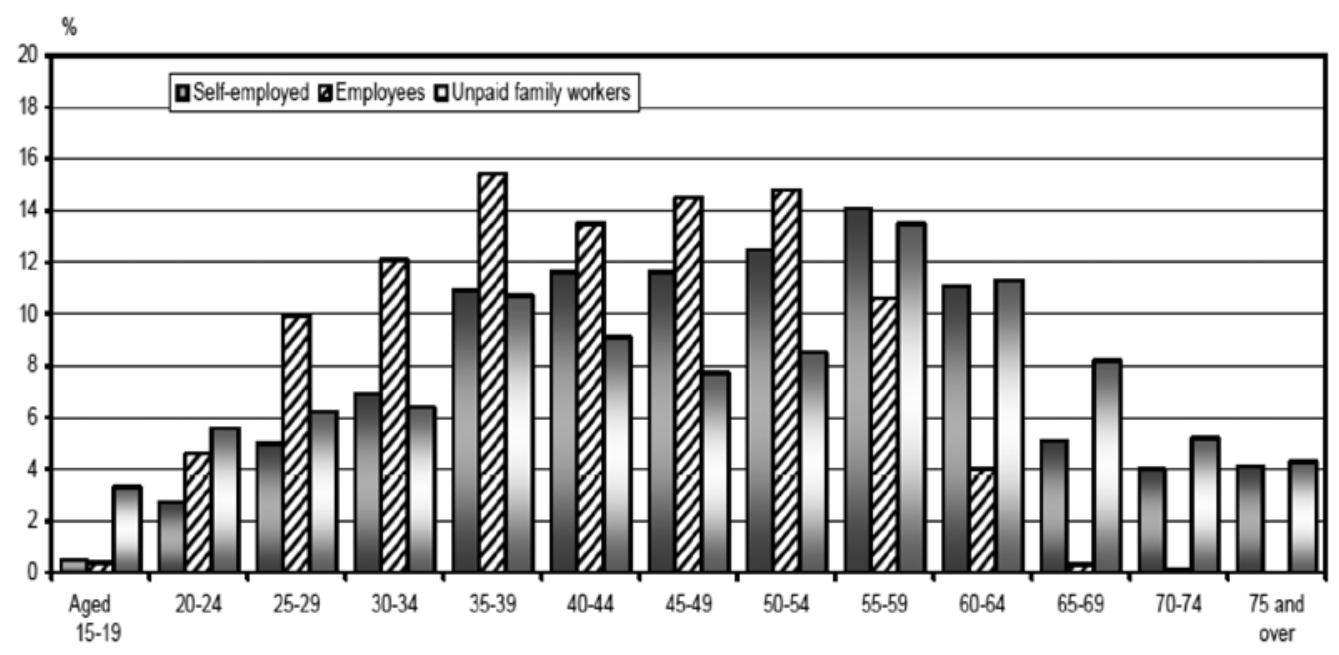

Source: Statistical Office of the Republic of Serbia, 2014.

Bearing in mind these results, as well as long-term high unemployment rate of young people, the question is why something is not done in terms of encouraging the young towards entrepreneurship in Serbia, given that this is a real alternative for the employment of young people.

One of the reasons may be the lack of professional experience and practical training, which can be an aggravating factor for starting one's own business. Another is that the young are confronted with the problem of underdeveloped entrepreneurial skills as a result of the lack of adequate educational programs in secondary schools and universities that would encourage the development

\footnotetext{
15 Statistical Office of the Republic of Serbia. (2014): Labour Force Survey, 2013. Statistical Office of the Republic of Serbia, Belgrade.

16 Ibid.
} 
of entrepreneurship among them ("RS Official Gazette", number 55/05, 71/05 - correction, 101/07, 65/08, 16/11, 68/12 - US, 72/12, 7/14 - US and 44/14). By introducing entrepreneurship education in the education system of the country the number of young people who decide to start their business would increase. The achievement of economic goals is based on the use of new ideas, information and the acquisition of new skills. ${ }^{17}$ Therefore, the strategy for development of entrepreneurship and competitiveness for the period from 2014 to 2020 was defined. For this reason, a large number of secondary schools and some universities initiated projects for student entrepreneurship, often along with the support of sponsors. University centres that provide development support services to SMEs may also play a vital role in the economic growth of a country. ${ }^{18}$ Among the most significant projects and initiatives that are currently being implemented in Serbia are: 'The reform of vocational education and training in Serbia", "Achievement of the young" - student entrepreneurship project, the program "Youth Entrepreneurship", the project "Centre Southeast Europe for Entrepreneurship Education" ("RS Official Gazette", number 55/05, 71/05 correction, 101/07, 65/08, 16/11, 68/12 - US, 72/12, 7 / 14 - US and 44/14).

However, one important thing has to be taken into consideration, and that is the level of enthusiasm and motivation of young people in terms of entrepreneurship, with the aim of overcoming the problem of unemployment, which is why the following research was undertaken.

\section{Research method}

In order to analyze the level of interest and motivation of young people in terms of entrepreneurship, the study emphasizes measuring "soft" factors such as perceptions, beliefs and intentions, in compliance with the Social Cognitive Career Theory - SCCT. ${ }^{19}$ The survey focused on two broad themes: 1) understanding the interest and goals (long- and short-term) towards an entrepreneurial career and;2) understanding the students view on relevant barriers and support factors affecting their career choices.

17 Jovancai, A., Tošović-Stevanović, A. (2013): The influence of education and labor force on competitiveness of enterprises and economy growth, Megatrend Review, Vol. 10 (4) 2013, 83-95.

18 Mitanoski, T., Kojić, J., Levi Jakšić, M., Marinković, S. (2013): Developing SMEs through University Support Centres: a Comparative Analysis. Management Journal for Theory and Practice Management, DOI: 10.7595/management.fon.2013.0010.

19 Lent, R. W., Brown, S. D., Hackett, G. (2000): Contextual supports and barriers to career choice: A social cognitive analysis. Journal of Counseling Psychology, 47(1), 36-49. 


\subsection{Sample}

The research was done from October to December 2011. Students from three different universities (four faculties) in Belgrade, Serbia, participated in this study. Sample data collection method was both paper- and online based due to the different digital possibilities at the Universities. The online-based survey was a faster method of data collection and provided an efficient way of distribution to respondents. There were no differences between those two surveys other than the method of data collection.

The total population was 359 participating students, with an age ranging from 21 to 43 years. About $90 \%$ of the respondents were in the age span of 22 to 25 years. The gender distribution was $67 \%$ female and $33 \%$ male students. Table 2 and 3 display descriptive data.

Table 2. Respondent frequency based on age.

\begin{tabular}{|c|c|c|}
\hline Age & Respondents, $\mathbf{n}$ & $\%$ \\
\hline $21-25$ & 330 & 91,9 \\
\hline $26-30$ & 24 & 6,7 \\
\hline $34-43$ & 5 & 1,4 \\
\hline Total & 359 & 100 \\
\hline
\end{tabular}

Table 3. Respondent frequency based on gender.

\begin{tabular}{|c|c|c|}
\hline Gender & Respondents, $\mathbf{n}$ & $\%$ \\
\hline Women & 239 & 66,6 \\
\hline Men & 120 & 33,4 \\
\hline Total & $\mathbf{3 5 9}$ & $\mathbf{1 0 0}$ \\
\hline
\end{tabular}

Final year university students were chosen as the target population for several reasons: 1) they are close to graduation and consequently, career choice decisions, 2) the high youth unemployment will affect many of these individuals in the years to come and, 3) the government initiated program for entrepreneurial education suggests there is a need for more understanding of interest and driving factors towards entrepreneurial careers.

The data was collected from the Faculty of Economics, University of Belgrade; Megatrend University; Singidunum University and the Faculty of Organizational Sciences, University of Belgrade (see Table 4.). 
Table 4. Respondent frequency based on faculty and university.

\begin{tabular}{|l|c|c|}
\hline \multicolumn{1}{|c|}{ Faculty / University } & Respondents, $\mathbf{n}$ & $\%$ \\
\hline $\begin{array}{l}\text { Faculty of Economics, } \\
\text { University of Belgrade }\end{array}$ & 103 & 28,7 \\
\hline Megatrend University & 54 & 15 \\
\hline Singidunum University & 72 & 20,1 \\
\hline $\begin{array}{l}\text { Faculty of Organizational Sciences, } \\
\text { University of Belgrade }\end{array}$ & 130 & 36,2 \\
\hline \multicolumn{1}{|c|}{ Total } & 359 & 100 \\
\hline
\end{tabular}

\subsection{Measures}

The questions in this study were based on the modified SCCT model by Lent, R. W., Brown, S. D., \& Hackett, G. (1994, 2000). The questionnaire contained 6 independent and 21 dependent variables, covering background information, distal- and proximal influences. The 21 questions stated as dependent variables were presented as ordinal variables with a 7-point Likert scale ranging from 1 "I strongly disagree" to 7 "I strongly agree" and 4 as neutral. The independent variables provided important basic background data on the respondents' properties and experience related to entrepreneurship. All variables (and questions) in the questionnaire were categorized using the modified SCCT model, in three different domains: Proximal influences, distal influences and interest and goals.

\section{Reliability and validity}

Variables from the survey were analyzed in order to find correlations or relationships based on the modified SCCT model. The analysis of the survey data was based on descriptive analysis, one-sample t-test for validity testing, bivariate Pearson's correlations and mean comparison analysis using ANOVA. These are rather standard analysis methods for quantitative studies, as recommended by Bryman and Bell. ${ }^{20}$ SPSS was used as the main software and tool for the analysis and frequency presentation. Correlations and mean variance were tested on a $p$ $<.05$ level of significance. Furthermore, collecting data from multiple universities improves the validity and generalization probability.

\section{Results and discussion}

Based on the information of descriptive analysis, male students represented only one third $(33,4 \%)$ of the sample. The age among the respondent's varied between 21 and 43 years, where 91,9\% were in the age span of 21-25 years.

$20 \quad$ Bryman, A., Bell, E. (2005): Företagsekonomiska Forskningsmetoder. Malmö: Liber. 
The population consisted of $65 \%$ students from public and $35 \%$ from private universities. A few students, $15,9 \%(n=57)$, had previous experience of entrepreneurship whereas a majority, $60 \%(n=217)$ had relations to entrepreneurs. Of those who had entrepreneurial experience, $86 \%$ stated that they had relations to entrepreneurs. The gender distribution for those with entrepreneurial experience was represented by $47,5 \%$ female and $52,6 \%$ male respondents. The even distribution might be an effect of the uneven distribution regarding the whole sample. The descriptive analysis also showed that students with entrepreneurial experiences were evenly distributed among the different universities. The same was found to be true of personal relations to entrepreneurs.

One of the hypotheses put forward in the study was: H1. Final year students in Serbia will show at least the same or higher interest towards entrepreneurial careers as the general working adult population.

The hypothesis was constructed in order to compare the sample with the report of the Global Entrepreneurship Monitoring (Global Entrepreneurship Monitor - GEM), which represents the largest study of enterpreneurial trends and dynamics in the world. Within the Global Entrepreneurship Monitoring, the role of entrepreneurship in many countries is investigated, revealing the basic characteristics of these countries related to their entrepreneurial activities and opportunities. Their program has three main objectives: ${ }^{21}$

1. identifying differences in relation to the level of entrepreneurial activity among countries

2. revealing certain country factors that influence the achievement of higher levels of entrepreneurship

3. identifying the level of political consciousness that leads to improvements in the level of entrepreneurial activity at level one country.

This approach provides a detailed picture of the behavior of individuals with regard to starting and running a business, which is why their approach is taken for comparison with the results of this test.

Domains and variables the interest domain was represented by two questions (q1. I am seriously thinking about starting a firm and q2. It is desirable for me to become an entrepreneur) in the questionnaire. The two questions represent interest in different ways. The $q 1$ measures intentions to start a business (interest by intentions) while $q 2$ measures desirability to start entrepreneurial careers (interest by desirability), as it can be seen in Table number 5 and 6 .

$21 \quad$ Bosma, N., Levie, J. (2009): 2009 Global Report. Global Entrepreneurship Monitor, GEM. Retrieved from http://www.gemconsortium.org 
Table 5. Question 1 - I am seriously thinking about starting a firm.

\begin{tabular}{|c|c|c|c|c|}
\hline & Frequency & Percent & Valid Percent & $\begin{array}{c}\text { Cumulative } \\
\text { Percent }\end{array}$ \\
\hline I fully disagree & 37 & 12,3 & 12,3 & 12,3 \\
\hline $\mathbf{2}$ & 45 & 14,9 & 14,9 & 27,2 \\
\hline $\mathbf{3}$ & 44 & 14,6 & 14,6 & 41,7 \\
\hline $\mathbf{4}$ & 82 & 27,2 & 27,2 & 68,9 \\
\hline $\mathbf{5}$ & 47 & 15,6 & 15,6 & 84,4 \\
\hline $\mathbf{6}$ & 25 & 8,3 & 8,3 & 92,7 \\
\hline I fully agree & 22 & 7,3 & 7,3 & 100 \\
\hline Total & 302 & 100 & 100 & \\
\hline
\end{tabular}

In the report of the Global Entrepreneurship Monitoring, entrepreneurial intentions and desirability measured $22 \%$ and $69 \%$ respectively for adult working population in Serbia. The $22 \%$ for entrepreneurial intentions excluded individuals with previous experience of entrepreneurship. To be able to compare the findings with the statistics from the report of the GEM from 2009 the results for $q 1$ were first filtered to exclude all individuals with entrepreneurial experience. The sample size for q1 was reduced to $302 .^{22}$

The means for $q 1$ and $q 2$ were $\mu q 13.93$ and $\mu q 25.23$ respectively. This implies the correspondents show less positive answers towards interest by intentions than interest by desirability, which corresponds with the results from the GEM 2009 Global Report. Furthermore, the frequency of positive answers in $q 1$ and $q 2$ were counted using the frequency of correspondents who answered 5 or higher on the Likert scale. ${ }^{23}$ The results showed that the frequency of positive answers for $q 1$ was 0.311 (31\%) and for $q 2$ was 0.701 (70\%). This implies that $31 \%$ of all students without previous entrepreneurial experience seriously think about starting a business (have entrepreneurial intentions) and $70 \%$ of all students, including those with entrepreneurial experience, consider entrepreneurship as a desirable career choice.

\footnotetext{
22 Bogdanović, D., Fuchs S. (2012): Entrepreneurial interest and goals among final year university students - The case in Belgrade, Serbia, Bachelor's thesis, Stockholm School of Business.

$23 \quad$ Ibid.
} 
Table 6. Question 2 - It is desirable for me to become an entrepreneur.

\begin{tabular}{|c|c|c|c|c|}
\hline & Frequency & Percent & Valid Percent & $\begin{array}{c}\text { Cumulative } \\
\text { Percent }\end{array}$ \\
\hline I fully disagree & 13 & 3,6 & 3,6 & 3,6 \\
\hline $\mathbf{2}$ & 19 & 5,3 & 5,3 & 8,9 \\
\hline $\mathbf{3}$ & 24 & 6,7 & 6,7 & 15,6 \\
\hline $\mathbf{4}$ & 51 & 14,2 & 14,2 & 29,8 \\
\hline $\mathbf{5}$ & 66 & 18,4 & 18,4 & 48,2 \\
\hline $\mathbf{6}$ & 80 & 22,3 & 22,3 & 70,5 \\
\hline I fully agree & 106 & 29,5 & 29,5 & 100 \\
\hline Total & 359 & 100 & 100 & \\
\hline
\end{tabular}

Great similarities are found comparing the findings with the results of the GEM. The positive answer frequency for $q 1$ was only $9 \%$ higher than the rate in GEM 2009 Report (31\% vs. $22 \%$ ) and the frequency for $q 2$ was almost the same as for the one in GEM 2009 Report (70\% vs. 69\%). This would suggest that the interest towards an entrepreneurial career among final year university students is higher or in close proximity to that of the general adult working population, which means that the hypothesis $\mathrm{H} 1$ has been confirmed.

\section{Conclusion}

In all of the official analyses in Serbia involving active population, the young ones are characterized by extremely low activity and the unemployment rate which is much higher than the unemployment rate of the general population. Given that there is a very high percentage of the young people who are first-time job seekers and that a large number are the long-term unemployed, with still a very small number opting for self-employment, the research was conducted with the aim of determining the level of interest and motivation of young people in terms of entrepreneurship, with the aim of overcoming the unemployment problem.

The results of the conducted analysis show that $70 \%$ of students are interested in entrepreneurial careers and $30 \%$ of students have set a goal to become entrepreneurs. These results suggest entrepreneurial initiative by professors, students and professional organizations that are focused on encouraging entrepreneurship, especially among young people, and strengthening students' interests in terms of entrepreneurship.

The results revealed that there are significant differences in interest between individuals who know entrepreneurs and those who do not know them. In addition, the research shows that there is a gender difference in terms 
of entrepreneurial objectives, that is, intention. Male students have higher aspirations towards becoming entrepreneurs, with both short-term (5 years since graduation) and long-term perspective (at some point during the professional career). Additionally, we can conclude that the final year students in Serbia who participated in this study are interested in entrepreneurship and some of them already have entrepreneurial goals.

However, there seems to be a lack of initiatives to support and promote entrepreneurship among young people in Serbia. There seems to be understanding of the problem, but the lack of research concerning interests and activities necessary for achieving the objectives.

Finally, the question is why, due to this high unemployment rate of the young in Serbia, something particular has not been done to encourage and develop the entrepreneurial spirit, as a real alternative employment.

\section{Literature}

- Avlijaš, R. (2010): Preduzetništvo. Beograd, Univerzitet Singidunum.

- Berkowitz, D., DeJong, D. N. (2005): Entrepreneurship and Post-socialist Growth, Oxford Bullentin of Economics and Statistics, 67, 0305-9049.

- Bosma, N., Levie, J. (2009): 2009 Global Report. Global Entrepreneurship Monitor, GEM. Retrieved from http://www.gemconsortium.org

- Bubalo-Živković, M., Lukić, T. (2015): Mladi u Srbiji početkom 21. veka, Republički zavod za statistiku, Beograd.

- Bogdanović, D., Fuchs S. (2012): Entrepreneurial interest and goals among final year university students - The case in Belgrade, Serbia, Bachelor's thesis, Stockholm School of Business.

- Bogetić, S., Đorđević, Đ., Ćoćkalo, D. (2014): Odnos mladih u Republici Srbiji prema pokretanju sopstvenog biznisa - regionalni aspekti, Ekonomski vidici, XIX, br. 2-3, 303-312.

- Bryman, A., Bell, E. (2005): Företagsekonomiska Forskningsmetoder. Malmö: Liber.

- Bygrave W. D., Zacharakis A. (2010): Entrepreneurship. Wiley, 2 edition.

- Centar za visoke ekonomske studije - CEVES (2014): Preduzetništvo u Srbija - nužda ili prilika, Beograd, www.ceves.org.rs.

- Demirgüc-Kunt, A., Klapper, F. L., Panos, A. G. (2011): Entrepreneurship in post-conflict transition: The role of informality and access to finance, Economics of Transition, 19(1), 27-78.

- Henderson, R., Robertson, M. (1999): Who wants to be an entrepreneur? Young adult attitudes to entrepreneurship as a career. Education + Training, 41(5), 236-245. 
- Iakovleva, T., Kolvereid, L., Stephan, U. (2011): Entrepreneurial intentions in developing and developed countries. Education + Training, 53(5), 353-370.

- International Labour Organization (2014): World of Work Report 2014: Developing with jobs / International Labour Office. Geneva: ILO, 2014

- Jovancai, A., Tošović-Stevanović, A. (2013): The influence of education and labor force on competitiveness of enterprises and economy growth, Megatrend Review, Vol. 10 (4) 2013, 83-95.

- Kelley, D. J., Singer, S., Herrington, M. (2012): 2011 Global Report, Global Entrepreneurship Monitor, GEM. Retrieved from http://www.gemconsortium.org

- Lent, R. W., Brown, S. D., Hackett, G. (2000): Contextual supports and barriers to career choice: A social cognitive analysis. Journal of Counseling Psychology, 47(1), 36-49.

- Lent, R. W., Brown, S. D., Hackett, G. (1994): Toward a Unifying Social Cognitive Theory of Career and Academic Interest, Choice, and Performance. Journal of Vocational Behavior, 45,79-122.

- Mitanoski, T., Kojić, J., Levi Jakšić, M., Marinković, S. (2013): Developing SMEs through University Support Centres: a Comparative Analysis. Management Journal for Theory and Practice Management, DOI: 10.7595/ management.fon.2013.0010.

- Nabi, G., Linan, F. (2011): Graduate entrepreneurship in the entrepreneurship developing world: intentions, education and development. Education + Training, 53(5), 325-334.

- Petrović, D. (2016): Makroekonomski ambijent u funkciji podsticanja inovacija I preduzetništva - primer države Izrael -, Megatrend Review, Vol. 13 (1) 2016, 1-35.

- ProConcept. (2009): Smisli Biznis, Osnovna Projektna Studija, http://smislibiznis.rs/322/

- Ristanović. V. (2014): Agonija nezaposlenosti u Evrozoni, Megatrend Review, Vol. 11 (2) 2014, 95-117.

- Statistical Office of the Republic of Serbia. (2014): Labour Force Survey, 2013. Statistical Office of the Republic of Serbia, Belgrade.

- Statistical Office of the Republic of Serbia. (2015): Labour Force Survey, 2014. Statistical Office of the Republic of Serbia, Belgrade.

- Sinclair, R. F. (2008): The First Step Towards a Theory of Entrepreneurial Career. United States Association for Small Business and Entrepreneurship, USASBE, 2008 Proceedings, 773-796. http://www.ef.uns.ac.rs/gem/

- Timmons, J. A., Spinelli, S. J. (2003): New Venture Creation: Entrepreneurship for the 21st Century. McGraw-Hill/Irwin.

- Wang C. K., Wong P. (2004): Entrepreneurial interest of university students in Singapore. Technovation, 24, 163-172.

- $\quad$ http://www.mpn.gov.rs. 


\section{NEZAPOSLENOST MLADIH I PREDUZETNIŠTVO U SRBIJI}

Problem nezaposlenosti je jedno od ključnih pitanja svake savremene ekonomije $i$ predstavlja jedan od najvažnijih indikatora efikasnosti jedne privrede. Veći stepen preduzetničkog interesovanja i aktivnosti može da bude važan deo unapređenja ekonomskog razvoja, međutim većina građana, a posebno mladih ljudi, više su okrenuti ka pronalaženju posla nego započinjanju sopstvenog. Zato je primarni cilj sprovedenog istraživanja, bolje razumevanje zainteresovanosti studenata završnih godina studija na fakultetima u Srbiji, u pogledu preduzetničke karijere i odredivanje ključnih faktora koji utiču na to. Istraživanje se oslanja na modifikaciju modela socijalne kognitivne teorije, fokusirajući se pre svega na interese i ciljeve studenata u pogledu preduzetništva.

Ključne reči: nezaposlenost, preduzetništvo, karijera, pokretanje sopstvenog biznisa, interesi i ciljevi mladih. 